\title{
AIDS patients have increased surfactant protein $D$ but normal mannose binding lectin levels in lung fluid Kondwani C Jambo ${ }^{1}$, Neil French ${ }^{2}$, Ed Zijlstra ${ }^{3}$ and Stephen B Gordon*4
}

\author{
Address: ${ }^{1}$ Malawi-Liverpool-Wellcome Trust Clinical Research Programme, Blantyre, Malawi, ${ }^{2}$ Wellcome Trust/LEPRA Karonga Prevention Study, \\ London School of Hygiene and Tropical Medicine, Chilumba, Malawi, ${ }^{3}$ Department of Medicine, University of Malawi College of Medicine, \\ Blantyre, Malawi and ${ }^{4}$ Liverpool School of Tropical Medicine, Liverpool, UK \\ Email: Kondwani C Jambo - kjambo@mlw.medcol.mw; Neil French - n.french@lshtm.ac.uk; Ed Zijlstra - eezijlstra@malawi.net; \\ Stephen B Gordon* - sbgordon@liverpool.ac.uk \\ * Corresponding author
}

Published: 13 June 2007

Respiratory Research 2007, 8:42 doi:10.1 I86/I465-992I-8-42

This article is available from: http://respiratory-research.com/content/8/l/42

This is an Open Access article distributed under the terms of the Creative Commons Attribution License (http://creativecommons.org/licenses/by/2.0), which permits unrestricted use, distribution, and reproduction in any medium, provided the original work is properly cited.

\begin{abstract}
Background: Surfactant protein D (SP-D) and Mannose Binding Lectin (MBL) are collectins that have opsonic and immunoregulatory functions, are found in lung fluid and interact with the human immunodeficiency virus (HIV). We compared collectin levels in lung fluid and serum from HIV infected and normal subjects to determine if alterations in lung collectin levels were associated with HIV infection and might result in increased susceptibility to other pulmonary infections.
\end{abstract}

Methods: Blood and bronchoalveolar lavage samples were collected from 19 HIV-infected individuals and $17 \mathrm{HIV}$-uninfected individuals, all with normal chest $X$ ray at time of study. HIV viral loads and peripheral blood CD4+ $T$ cell counts were measured in all subjects. SP-D was measured in lung fluid, and MBL in both lung fluid and serum.

Results: SP-D levels were not significantly different in lung fluid from HIV-uninfected (median $406.72 \mathrm{ng} / \mathrm{ml}$ ) and HIV-infected individuals with high CD4 count (CD4 >200) (median $382.60 \mathrm{ng} /$ $\mathrm{ml}$ ) but were elevated in HIV-infected individuals with low CD4 count (median $577.79 \mathrm{ng} / \mathrm{ml}$; Kruskall Wallis $p<0.05$ ). MBL levels in serum were not significantly different between HIVuninfected and HIV-infected individuals (median $1782.70 \mathrm{ng} / \mathrm{ml}$ vs $2639.73 \mathrm{ng} / \mathrm{ml}$ ) and were not detectable in lung fluid.

Conclusion: SP-D levels are increased in lung fluid from AIDS patients but not in patients with early HIV infection. MBL levels are not altered by HIV infection or AIDS. There is no evidence that altered pulmonary collectin levels result in susceptibility to infection in these patients.

\section{Background}

Surfactant protein D (SP-D) and mannose binding lectin (MBL) are members of the human collectin system. The collectins are a group of molecules characterised by a collagenous region and a lectin (carbohydrate-binding) domain which together give the members structural and functional similarity[1]. The collectins function in innate immunity as opsonins and agglutinins but also have important pro- and anti-inflammatory immunomodulatory functions[2]. Surfactant protein D is produced mainly in the lung by alveolar type II cells and bronchiolar epithelial cells, but has also been reported at other mucosal surfaces[3]. Mannose binding lectin is produced in the liver as an acute phase protein which may leak from 
the systemic circulation at the site of inflammation in the lungs, and provide an optional host defence mechanism[4].

Alterations in collectin levels are associated with susceptibility to pulmonary infection. Levels of SP-D are decreased in bronchoalveolar lavage fluid of cystic fibrosis patients and relative collectin deficiency is inversely related to inflammation in these patients[5]. SP-D is critical in modulating responses to respiratory viral infections[6] and bacterial pneumonia[7]. It is present in serum of healthy adults ranging from $158-3711 \mathrm{ng} / \mathrm{ml}$ but SP-D in serum is considered to reflect damage to or response from epithelial cells to inflammation[7]. Reduced levels of MBL in serum are associated with meningococcal invasion through the respiratory $\operatorname{tract}[8,9]$ and MBL was recently shown to be a critical determinant of macrophage ingestion of meningococci[10]. MBL was present in bronchoalveolar lavage samples from patients with pneumonia at concentrations ranging from 0.011 to $0.078 \mathrm{mg} / \mathrm{ml}$ but none was found in bronchoalveolar lavage from healthy adults[11].

SP-D and MBL play an important role in defence against HIV infection. SP-D binds to the HIV surface protein gp120 and has significant HIV-binding and inhibitory activities[3]. SP-D expression has recently been measured in both respiratory and non-respiratory mucosa including the oral cavity and female genital tract[12,13] suggesting a possible role in sexual or vertical transmission of HIV. SP-D inhibits HIV infectivity at significantly lower concentrations than MBL[3]. Increased susceptibility to HIV infection in patients with MBL insufficiency or protection from HIV in those with high MBL levels has been reported[14,15] but the effect of reduced levels of MBL on HIV disease progression are controversial[16,17]. MBL initiates complement activation[18] and can also inhibit DC-SIGN-mediated transfer of HIV from dendritic cells to T cells[19].

Our hypothesis was that reduced levels of collectins in BAL might result in increased susceptibility to pneumonia among AIDS patients. Our goal in this study was to determine if HIV status (stratified by CD4 count) was associated with altered levels of collectins in BAL and serum.

\section{Methods}

\section{Subject recruitment and sample collection}

Adult Malawians were recruited by advertisement and gave written informed consent to participate in a study of pulmonary immune responses to infection. This study included bronchoscopy with lavage, serum sampling and HIV testing. This study was approved by the Liverpool School of Tropical Medicine Research Ethics Committee and the College of Medicine Research Ethics Committee of the University of Malawi.

Patients attended recruitment clinic when venous blood was collected. Bronchoscopy with lavage was carried out a few days later as previously described[20]. Briefly, a fibreoptic bronchoscope was wedged in a sub-segmental bronchus of the right middle lobe and $200 \mathrm{ml}$ of warmed sterile saline introduced in 4 aliquots. Bronchoalveolar lavage (BAL) obtained by this method typically yields 120 ml of cellular fluid. BAL and venous blood samples were transferred on ice immediately to the laboratory and centrifuged to remove the cellular pellet. Supernatant fluid and serum obtained from venous blood were stored at $80^{\circ} \mathrm{C}$ for future assay.

\section{Laboratory assays}

Serum HIV viral loads and CD4+ T cell counts were determined by Amplicor HIV-1 Monitor Test version 5.0 and Becton Dickinson FACS Count, respectively.

Measurement of SP-D in BAL was done using an SP-D Sandwich ELISA kit (BioVender GmbH, Germany). The Standards and Quality Controls used in this kit are both human recombinant protein based. The Assay was done in accordance with the manufacturer's instructions.

Measurement of MBL in serum and BAL was done using an MBL ELISA kit (Sanquin, Netherlands). The kit has a minimum detection level of $9.0 \mathrm{ng} / \mathrm{mL}$ and a measurable concentration range of 9.0 to $350 \mathrm{ng} / \mathrm{mL}$. The Assay was done in accordance with the manufacturer's instructions.

\section{Statistical Analysis}

HIV-infected patients were stratified into two groups according to peripheral blood CD4+ T lymphocyte cell count greater or less than 200 cells $/ \mathrm{ml}$. This corresponds to a clinical diagnosis of AIDS. We compared levels of SP$\mathrm{D}$ and MBL in BAL and serum by HIV status using Mann Whitney test and Kriskall Wallis test. The results were reported as median with interquartile ranges. Intercooled Stata 9.2 was used to perform all the statistical operations in this study. All the graphs in this study were produced using GraphPad Prism 5.00.

\section{Results \\ Subjects}

Blood and BAL samples were collected with informed consent from 19 HIV-infected and 17 HIV-uninfected individuals, all of whom were healthy at the time of bronchoscopy and had a normal chest $\mathrm{X}$ ray. The demographic and clinical characteristics of the three groups are summarised in Table 1. There was no significant difference in age distribution between the groups. There was a higher mean HIV viral load in both the serum and BAL of subjects with 
CD4 counts less than 200 cells/ $\mu$ (clinical AIDS) than in HIV infected subjects with higher CD4 counts. None of the HIV infected subjects was on anti-retroviral therapy at the time of the study. Three subjects with AIDS were current cigarette smokers of 3,5 and 20 cigarettes per day (1.5, 5 and 15 pack-years) and two normal subjects were current smokers of 5 and 6 cigarettes per day (both 3 packyears). One HIV infected subject with a normal CD4 count (greater than 500 cells/ $\mu \mathrm{l}$ ) had stopped smoking in 1971 (1.5 pack-years).

\section{Surfactant Protein D in lung fluid during HIV infection}

The levels of SP-D in BAL of HIV positive individuals were compared with levels of SP-D in BAL of HIV-uninfected individuals. These levels were not significantly different with median SP-D in HIV uninfected $406.72 \mathrm{ng} / \mathrm{ml}$ compared to 463.05 in HIV infected (Mann Whitney $\mathrm{p}=0.32$ ) (Figure 1a). We also compared the levels of SP-D among normal subjects, HIV positive subjects with CD4 count $>200$ cells/ $\mu$ land patients with AIDS (CD4 count $<200$ cells $/ \mu \mathrm{l})$. SP-D levels were significantly higher in AIDS patients (median $577.79 \mathrm{ng} / \mathrm{ml}$ ) compared to normal subjects (median $406.72 \mathrm{ng} / \mathrm{ml}$; Kruskall Wallis p = 0.03) or HIV-infected individuals with CD4 count greater than 200 cells $/ \mu \mathrm{l}$ (median $382.60 \mathrm{ng} / \mathrm{ml}$; Kruskall Wallis $\mathrm{p}=$ 0.05) (Figure 1b).

As it has been reported that SP-D has significant HIVbinding and inhibitory activities exceeding MBL[12], we investigated the possibility that high levels of SP-D were associated with low viral loads in BAL. SP-D levels were found to have a weak relationship with BAL viral loads ( $\mathrm{p}$ $\left.<0.05, \mathrm{r}^{2}=0.26\right)$. We also compared SP-D concentration to CD4 count, it was found that there was a weak relationship between the two variables $\left(\mathrm{p}<0.05, \mathrm{r}^{2}=0.30\right)$

\section{Mannose Binding Lectin in serum and BAL during HIV infection}

MBL levels in serum compared by HIV status were not significantly different as shown in Figure 2a (median MBL in normal $1782.70 \mathrm{ng} / \mathrm{ml}$ compared to $2639.73 \mathrm{ng} / \mathrm{ml}$ in HIV infected; Mann Whitney $\mathrm{p}=0.58$ ). We also compared the levels of MBL among normal subjects, HIV positive subjects with CD4 count $>200$ and AIDS patients (CD4 count $<200$ cells/ $\mu$ l). MBL levels were not significantly dif- ferent among these three groups as shown in Figure $2 \mathrm{~b}$ (median MBL in normals $1782.70 \mathrm{ng} / \mathrm{ml}$ vs HIV positive individuals (CD4 count >200 cells/ $\mu \mathrm{l}$ ) $2291.73 \mathrm{ng} / \mathrm{ml}$ vs AIDS patients $2651.74 \mathrm{ng} / \mathrm{ml}$; Kruskall Wallis $\mathrm{p}=0.70$ ).

MBL levels in BAL were below the lower limit of detection in all samples. Using extrapolated data, MBL levels in BAL compared by HIV status showed no significant difference (median MBL in normal $0.283 \mathrm{ng} / \mathrm{ml}$ compared to 0.401 $\mathrm{ng} / \mathrm{ml}$ in HIV infected; Mann Whitney $\mathrm{p}=0.06$ ). MBL levels in BAL showed a significant correlation with MBL levels in serum in both HIV-infected and HIV-uninfected individuals $(\mathrm{p}<0.05)$. MBL levels in serum or BAL in HIV infected patients did not show significant correlation with CD4 count or HIV viral load in either plasma or BAL ( $p>$ $0.05)$.

\section{Discussion}

In this study, levels of SP-D and MBL in BAL and serum collected from HIV infected patients were not different from those in normal subjects. Among HIV infected patients, patients with AIDS had a higher SP-D than patients with higher CD4 counts. MBL levels in BAL were very low, and correlated with serum levels of MBL, which were not altered by HIV status or clinical AIDS.

Previous studies have shown that SP-D deficiency is associated with increased respiratory infection[7] and is associated with increased airway inflammation[5]. There was no evidence in this study to suggest that low SP-D level is a factor in the susceptibility of HIV infected patients to respiratory infection[21], or that lack of SP-D contributes to the pulmonary inflammation that is a feature of AIDS[22,23]. SP-D has been shown to bind to HIV envelope protein gp120 and inhibit HIV replication[3] so the increased SP-D levels seen in our subjects with AIDS may be an appropriate response, although we were not able to demonstrate a relationship between SP-D level and BAL HIV viral load. SP-D suppresses lymphocyte function by inhibiting $\mathrm{T}$ lymphocyte proliferation [24] therefore a decrease in CD4 count might be secondary to an increase in SP-D levels but we did not detect this association. Our patients were healthy and had normal chest radiographs but the increased SP-D seen in AIDS patients in this study is consistent with recent observations made of intensive

Table I: Demographic and clinical features of subjects in the study

\begin{tabular}{|c|c|c|c|}
\hline Clinical feature & Normal & HIV infected (CD4 >200 cells/ul) & AIDS patients (CD4<200 cells/ul) \\
\hline Gender M:F & $17: 2$ & $8: 2$ & $6: 1$ \\
\hline Age, Mean ( $\pm S D)$, years & $30(9.9)$ & $33.6(9.4)$ & $34.5(7.2)$ \\
\hline CD4+ T cell count, mean (range), cells/ $\mu \mathrm{l}$ & $606(512-978)$ & $493(368-675)$ & $149(46-179)$ \\
\hline Plasma HIV-I load, mean (range) copies/ml & 0 & $1.4 \times 10^{5}\left(0.008-4.0 \times 10^{5}\right)$ & $2.3 \times 10^{5}\left(0.3-6.6 \times 10^{5}\right)$ \\
\hline BAL Fluid HIV-I load, mean (range) copies/ml & 0 & $129(0-670)$ & $175(0-550)$ \\
\hline
\end{tabular}

Abbreviations: $\mathrm{BAL}=$ Bronchoalveolar Lavage, $\mathrm{SD}=$ Standard Deviation 


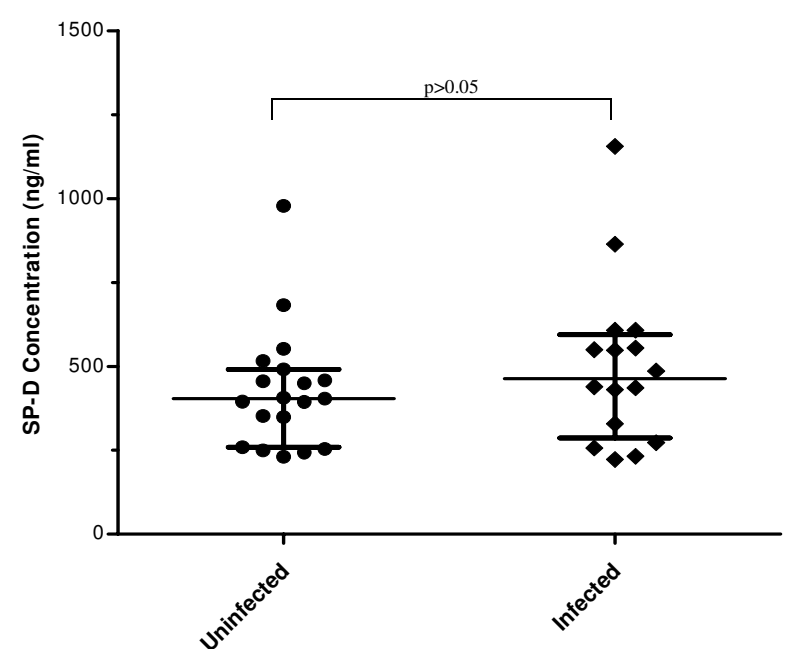

HIV Status

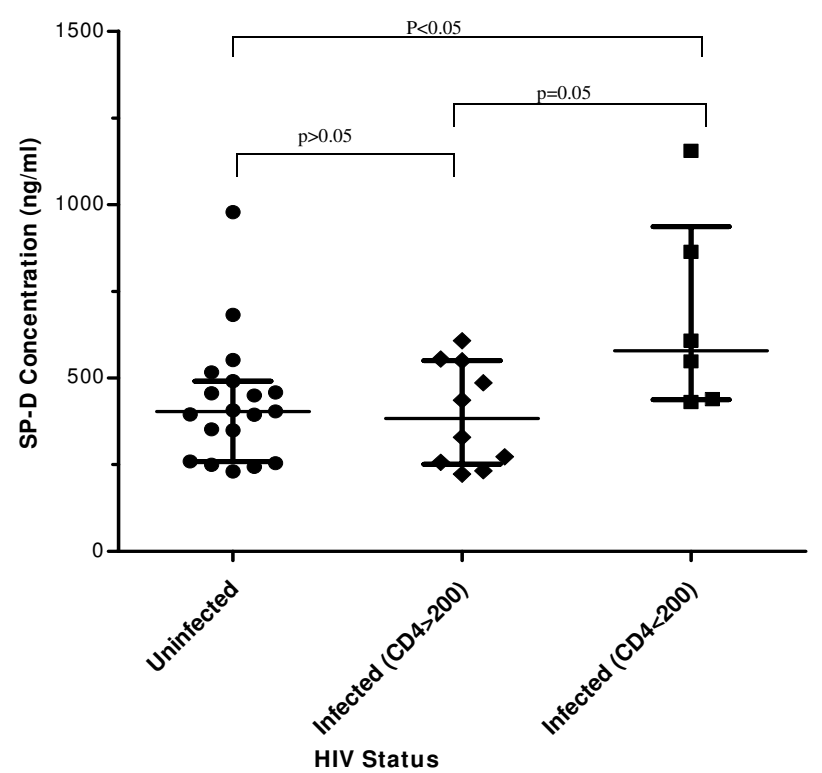

Figure I

Levels of SP-D in BAL of both HIV-uninfected and HIV positive individuals. The bars represent median and interquartile range. a). The analysis was performed on 19 HIV-uninfected and 16 HIV Positive subjects. b). The analysis was performed on 19 HIV-uninfected, 10 HIV Positive with CD4 count $>200$ and 6 AIDS patients (CD4 count $<200$ ).

care patients with pneumocytsis pneumonia in Germany[25].

MBL is a serum collectin that is found in lung at very low levels except in conditions of severe inflammation such as those that accompany pneumonia[11]. MBL leaks into the

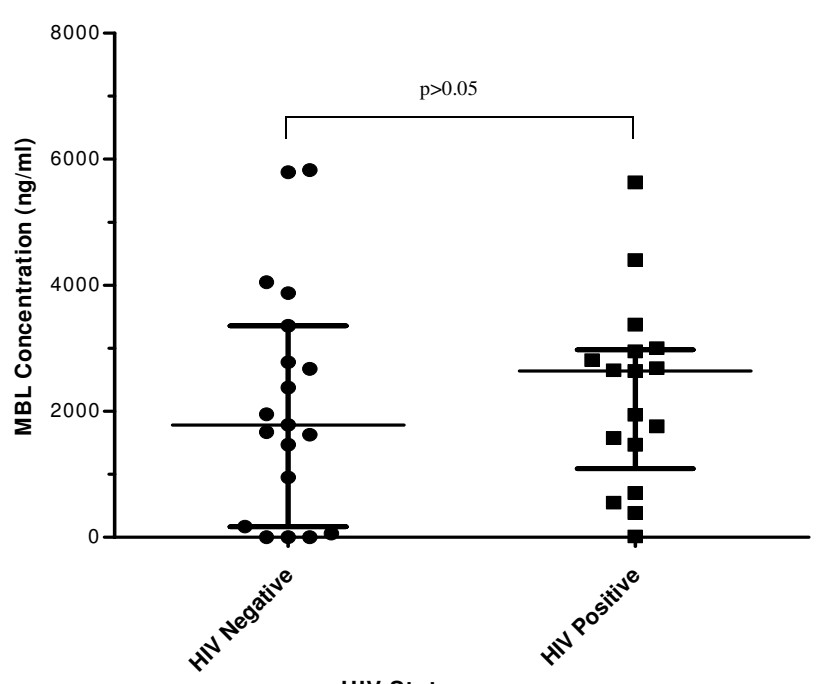

HIV Status

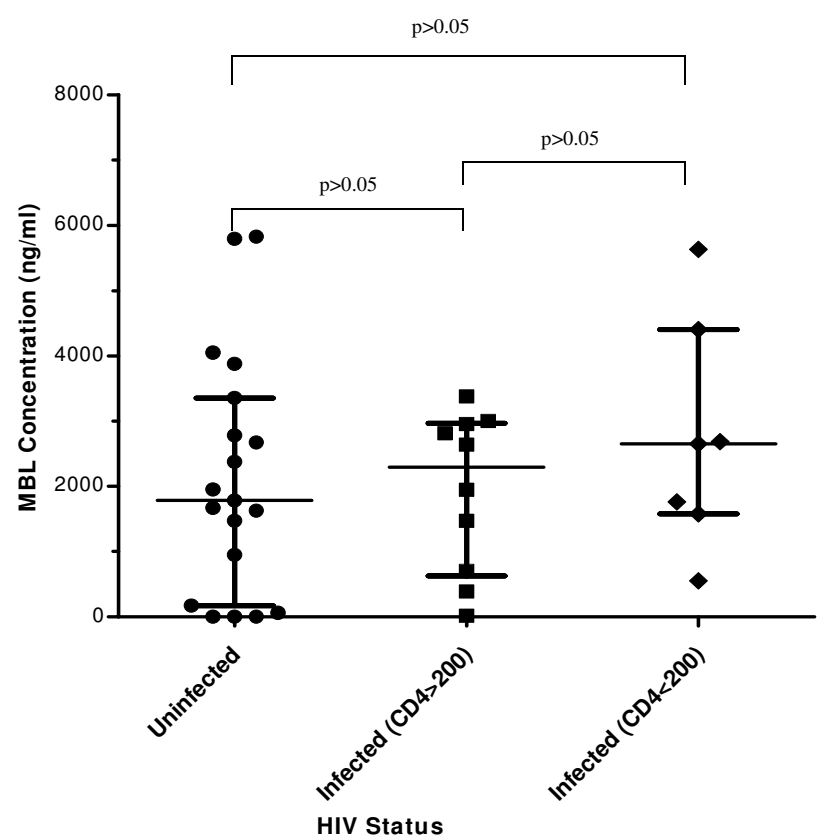

Figure 2

Levels of MBL in serum of both HIV-uninfected and HIV positive individuals. The bars represent median and interquartile range. a). The analysis was performed on 19 HIV-uninfected and 17 HIV Positive subjects. b). The analysis was performed on 19 HIV-uninfected, 10 HIV Positive with CD4 count > 200 and 7 AIDS patients (CD4 count < 200).

alveolar space in conditions of inflammation but levels do not increase as an acute phase protein[26]. We found that MBL levels were detectable but were not raised in BAL from HIV infected subjects or in subjects with AIDS, sug- 
gesting that the vascular integrity of the lung in these subjects was intact. We were able to correlate the MBL levels found in BAL with those in serum, both for HIV infected and normal subjects. We found no difference in MBL levels when we compared serum from normal subjects, HIV infected and AIDS patients. This differs from a study which showed a higher level of MBL in HIV infected patients[27] but is consistent with studies that showed no association between MBL level and either HIV infection, disease progression or AIDS[16,17]. Like SP-D, MBL binds HIV viral gp120 and can activate complement but we did not detect any association of MBL level with increased HIV viral load or AIDS.

\section{Conclusion}

There was no evidence that susceptibility to infection or inflammation in the lungs of AIDS patients was due to altered levels of the collectins SP-D or MBL.

\section{Competing interests}

The author(s) declare that they have no competing interests.

\section{Authors' contributions}

KCJ was involved in the study design of the study, laboratory measurements, data analysis, and manuscript writing. SBG recruited the patients, carried out bronchoscopy and lavage procedures, analysed the data and was involved in manuscript writing. NF was involved in patient recruitment, clinical follow-up and manuscript writing. EEZ supervised the study and was involved in manuscript writing. All authors read and approved the final manuscript.

\section{Acknowledgements}

We would like to thank Dr Helen Tolmie (LSTM, UK) for laboratory support, Herbert Longwe and Esther Gondwe (MLW, Malawi) for reading the manuscript and the Wellcome Trust for funding the work. This study was funded by Wellcome Trust grant number 06I23 I (Career Development Fellowship awarded to SG) and was part of the Malawi-Liverpool-Wellcome Programme of Clinical Tropical Research.

\section{References}

I. Davies J, Turner M, Klein N: The role of the collectin system in pulmonary defence. Paediatr Respir Rev 200I, 2:70-75.

2. Crouch EC: Collectins and pulmonary host defense. Am J Respir Cell Mol Biol 1998, 19:177-201.

3. Meschi J, Crouch EC, Skolnik P, Yahya K, Holmskov U, Leth-Larsen R, Tornoe I, Tecle T, White MR, Hartshorn KL: Surfactant protein D binds to human immunodeficiency virus (HIV) envelope protein gpI20 and inhibits HIV replication. J Gen Virol 2005, 86:3097-3107.

4. Summerfield JA: The role of mannose-binding protein in host defence. Biochem Soc Trans 1993, 21:473-477.

5. LeVine AM, Lotze A, Stanley S, Stroud C, O'Donnell R, Whitsett J, Pollack MM: Surfactant content in children with inflammatory lung disease. Crit Care Med 1996, 24:1062-1067.

6. White MR, Crouch E, Vesona J, Tacken PJ, Batenburg JJ, Leth-Larsen $\mathrm{R}$, Holmskov U, Hartshorn KL: Respiratory innate immune proteins differentially modulate the neutrophil respiratory burst response to influenza A virus. Am J Physiol Lung Cell Mol Physiol 2005, 289:L606-L6I6.

7. Leth-Larsen R, Nordenbaek C, Tornoe I, Moeller V, Schlosser A, Koch C, Teisner B, Junker P, Holmskov U: Surfactant protein D (SP-D) serum levels in patients with community-acquired pneumonia small star, filled. Clin Immunol 2003, 108:29-37.

8. Garred P, Madsen HO, Svejgaard A, Michaelsen TE: Mannose-binding lectin and meningococcal disease. Lancet 1999, 354:336.

9. Roy S, Knox K, Segal S, Griffiths D, Moore CE, Welsh KI, Smarason A, Day NP, McPheat WL, Crook DW, Hill AV: MBL genotype and risk of invasive pneumococcal disease: a case-control study. Lancet 2002, 359: I569-1573.

10. Jack DL, Lee ME, Turner MW, Klein NJ, Read RC: Mannose-binding lectin enhances phagocytosis and killing of Neisseria meningitidis by human macrophages. J Leukoc Biol 2005, 77:328-336.

II. Gomi K, Tokue Y, Kobayashi T, Takahashi H, Watanabe A, Fujita T, Nukiwa T: Mannose-binding lectin gene polymorphism is a modulating factor in repeated respiratory infections. Chest 2004, 126:95-99.

12. Leth-Larsen R, Floridon C, Nielsen O, Holmskov U: Surfactant protein D in the female genital tract. Mol Hum Reprod 2004, 10:149-154.

13. Madsen J, Kliem A, Tornoe I, Skjodt K, Koch C, Holmskov U: Localization of lung surfactant protein $D$ on mucosal surfaces in human tissues. J Immunol 2000, 164:5866-5870.

14. Ezekowitz RA, Kuhlman M, Groopman JE, Byrn RA: A human serum mannose-binding protein inhibits in vitro infection by the human immunodeficiency virus. J Exp Med 1989, 169:185-196.

15. Garred P, Madsen HO, Balslev U, Hofmann B, Pedersen C, Gerstoft J, Svejgaard A: Susceptibility to HIV infection and progression of AIDS in relation to variant alleles of mannose-binding lectin. Lancet 1997, 349:236-240.

16. McBride MO, Fischer PB, Sumiya M, McClure MO, Turner MW, Skinner CJ, Weber JN, Summerfield JA: Mannose-binding protein in HIV-seropositive patients does not contribute to disease progression or bacterial infections. Int J STD AIDS 1998, 9:683-688.

17. Nielsen SL, Andersen PL, Koch C, Jensenius JC, Thiel S: The level of the serum opsonin, mannan-binding protein in HIV-I antibody-positive patients. Clin Exp Immunol 1995, 100:21 9-222.

18. Holmskov U, Thiel S, Jensenius JC: Collections and ficolins: humoral lectins of the innate immune defense. Annu Rev Immunol 2003, 21:547-578.

19. Spear GT, Zariffard MR, Xin J, Saifuddin M: Inhibition of DC-SIGNmediated trans infection of $T$ cells by mannose-binding lectin. Immunology 2003, I I0:80-85.

20. Gordon SB, Molyneux ME, Boeree MJ, Kanyanda S, Chaponda M, Squire SB, Read RC: Opsonic phagocytosis of Streptococcus pneumoniae by alveolar macrophages is not impaired in human immunodeficiency virus-infected Malawian adults. J Infect Dis 200I, I 84:I345-I349.

21. Hirschtick RE, Glassroth J, Jordan MC, Wilcosky TC, Wallace JM, Kvale PA, Markowitz N, Rosen MJ, Mangura BT, Hopewell PC: Bacterial pneumonia in persons infected with the human immunodeficiency virus. Pulmonary Complications of HIV Infection Study Group. N Engl J Med 1995, 333:845-85I.

22. Mitchell DM, Clarke JR: Pulmonary function tests in HIV-I infection. 1995:232-254.

23. Twigg HL, Soliman DM, Day RB, Knox KS, Anderson RJ, Wilkes DS, Schnizlein-Bick CT: Lymphocytic alveolitis, bronchoalveolar lavage viral load, and outcome in human immunodeficiency virus infection. Am J Respir Crit Care Med 1999, 159: I439- 1444.

24. Borron PJ, Mostaghel EA, Doyle C, Walsh ES, McHeyzer-Williams MG, Wright JR: Pulmonary surfactant proteins $A$ and $D$ directly suppress CD3+/CD4+ cell function: evidence for two shared mechanisms. J Immunol 2002, 169:5844-5850.

25. Schmidt R, Markart P, Ruppert C, Temmesfeld B, Nass R, Lohmeyer J, Seeger W, Gunther A: Pulmonary surfactant in patients with Pneumocystis pneumonia and acquired immunodeficiency syndrome. Crit Care Med 2006, 34:2370-2376.

26. Perez-Castellano M, Penaranda M, Payeras A, Mila J, Riera M, Vidal J, Pujalte F, Pareja A, Villalonga C, Matamoros N: Mannose-binding lectin does not act as an acute-phase reactant in adults with community-acquired pneumococcal pneumonia. Clin Exp Immunol 2006, 145:228-234. 
27. Senaldi G, Davies ET, Mahalingam M, Lu J, Pozniak A, Peakman M, Reid $K B$, Vergani $D$ : Circulating levels of mannose binding protein in human immunodeficiency virus infection. J Infect 1995,

3I:145-148.

Publish with Bio Med Central and every scientist can read your work free of charge

"BioMed Central will be the most significant development for disseminating the results of biomedical research in our lifetime. " Sir Paul Nurse, Cancer Research UK

Your research papers will be:

- available free of charge to the entire biomedical community

- peer reviewed and published immediately upon acceptance

- cited in PubMed and archived on PubMed Central

- yours - you keep the copyright

Submit your manuscript here:

http://www.biomedcentral.com/info/publishing_adv.asp 